\title{
Ditadura, democracia e estado de exceção
}

\section{Dictatorship, democracy, and state of exception Américo Freire}

\section{Desarquivando a ditadura. Memória e justiça no Brasil. Cecília Macdowell Santos, Edson Teles e Fanaína de Almeida Teles (org.). São Paulo: Hucitec, 2009.}

Nas duas últimas décadas, os estudos históricos voltados para o exame da natureza do regime civil-militar brasileiro experimentaram um enorme impulso. Por certo, não faltam razões para explicar esse verdadeiro boom que, evidentemente, não é um fenômeno que diz respeito apenas ao Brasil. Basta consultar a programação dos inúmeros congressos internacionais que tratam de temáticas contemporâneas para se verificar a ampla presença de trabalhos voltados para a análise de experiências dramáticas vividas por indivíduos e grupos de diferentes sociedades sob o jugo de regimes ditatoriais.

\footnotetext{
Américo Freire é professor associado do Programa de Pós-Graduação em História, Política e Bens Culturais do Centro de Pesquisa e Documentação de História Contemporânea do Brasil (CPDOC) da Fundação Getulio Vargas (FGV), Rio de Janeiro, Brasil (americo.freire@fgv.br).

Resenha recebida em 7 de janeiro de 201le aprovada para publicação em 24 de fevereiro de 2011.
} 
No caso da produção recente sobre a ditadura brasileira, há duas vertentes de trabalho que têm despertado interesse e aberto caminho para novas incursões analíticas.

Uma delas está relacionada ao estudo de um fenômeno que, à falta de melhor denominação, pode ser chamado de institucionalização autoritária, o qual se associa aos processos pelos quais os governos militares levaram adiante $o$ propósito de demarcar-se das demais ditaduras por meio de aplicação de medidas assentadas em textos político-legais, fosse a carta constitucional, fosse a própria legislação autoritária. Tais iniciativas expressaram-se também no estabelecimento de relações ambíguas com diferentes instituições do Estado brasileiro, em particular com os poderes Judiciário e Legislativo, já que foram assegurados, para ambos, determinados espaços de atuação político-institucional.

Outro campo que tem sido privilegiado é o que examina, sob diferentes perspectivas, a transição política brasileira e suas implicações para o estabelecimento de uma nova ordem política democrática no país. Vários autores, com base no pressuposto de que se deve conceber a dinâmica da transição brasileira como uma via de mão dupla entre o Estado e amplas parcelas político-sociais, têm buscado estabelecer linhas de continuidade entre o processo gradualista e acordado de retirada dos militares do centro do poder, no qual a Lei de Anistia cumpriu papel decisivo, e as "estratégias de esquecimento" que foram e têm sido acionadas pelos governos civis da chamada "Nova República".

Lançado em 2009, em meio aos debates políticos e acadêmicos acerca da revisão da Lei de Anistia no Brasil, Desarquivando a ditadura nos propicia um excelente roteiro para o exame de algumas das questões historiográficas acima levantadas, além de muitas outras.

A obra é composta por dois volumes, ambos organizados em torno dos eixos "memória política" e "justiça". O primeiro volume, dirigido para o estudo dos anos de repressão política, é dividido em duas partes: um conjunto de artigos relativos às memórias e às histórias de diferentes atores que resistiram ao arbítrio; e um outro conjunto, dirigido ao estudo da ideologia militar e das instituições do Estado.

Três dos capítulos que compõem a primeira parte do livro abordam temas ainda muito pouco explorados na literatura sobre o regime. Antônio Luigi Negro brinda-nos com um interessante texto sobre as expectativas e angústias de mulheres revolucionárias que se envolveram na experiência de se integrar à produção como operárias. Valendo-se de um rico conjunto documental produzido à época pelas organizações que apostaram naquela prática, $\mathrm{o}$ autor traz nova abordagem ao tema, quando se propõe a lidar não apenas "com o que as militantes queriam fazer com as operárias, mas também o que as operárias fizeram com as militantes". 
Já Flamarion Maués acompanha a publicação e distribuição do livro Tortura: a história da repressão política no Brasil, de autoria do jornalista Antônio Carlos Fon e publicado pela Editora Global, em 1979. Em seu estudo, o autor examina, em primeiro lugar, a rede de relações que se estabeleceu entre setores da grande imprensa e o governo Geisel no contexto da aplicação do projeto de distensão política. Em seguida, coloca-nos a par da dinâmica própria do campo das pequenas editoras de oposição do país, do qual a Global foi um dos exemplos mais expressivos.

Na sequência, Tatiana Paiva apresenta em texto um extrato de sua original pesquisa acerca de um lado ainda obscuro do exílio: o do impacto daquela experiência nos filhos dos que se viram obrigados a sair do país por motivos políticos.

O texto de Janaína Teles a respeito da luta dos familiares de mortos e desaparecidos fecha a primeira parte do livro. Nele, a autora discorre sobre as estratégias acionadas pelos governos militares no sentido de promover o desaparecimento de militantes assassinados pelo regime, sem deixar de chamar atenção para o fato de que foi no período do "moderado" Geisel que se deu a intensificação dessa prática.

Na segunda parte do livro, três textos lidam com questões que dizem respeito diretamente ao tema da justiça, sendo que dois deles, o de Anthony Pereira e o de Kathia Martin-Chenut, se associam a um duplo movimento que tem dado bons frutos para a história política brasileira, a saber, o uso do método comparativo e a crescente aproximação de saberes entre a História, as Ciências Sociais e o Direito.

Anthony Pereira toma como objeto a maneira pela qual os regimes ditatoriais do Brasil, do Chile e da Argentina se relacionaram com seus sistemas judiciais para processar seus opositores. Para o autor, uma variável a se levar em conta nesse caso diz respeito às relações que historicamente foram sendo construídas entre as elites judicial e militar. Em outras palavras, quanto maior for o nível de integração entre esses dois atores, como no caso brasileiro, mais possível se a torna institucionalização da aplicação da justiça. Já Kathia Martin-Chenut examina a estruturação do Estado de exceção brasileiro à luz da legislação internacional sobre direitos humanos. Segundo a autora, estabeleceu-se no país um Estado de exceção complexo ou anômalo, dado que fundado em um sistema jurídico de alta complexidade, o qual foi expressão do "esforço de racionalização jurídica por parte dos detentores do poder, esforço que distingue o regime autoritário brasileiro de outros instaurados na América Latina”.

O segundo volume da obra dirige-se para o estudo da transição política e para o estabelecimento da ordem democrática no país. Dos capítulos que compõem a primeira parte, três discutem a Lei de Anistia brasileira sob diferentes 
perspectivas. O primeiro deles, de Samuel Soares e Larissa Prado, concentra o foco de análise no controle que os militares exerceram sobre o processo de anistia, assim como na análise das razões pelas quais a hierarquia militar utiliza-se do seu poder de veto para barrar quaisquer iniciativas que representem mudanças substantivas no espírito da norma aprovada em 1979. Já Glenda Mezarobba oferece-nos um quadro mais dinâmico da questão, quando acompanha em detalhes as políticas que têm sido adotadas pelos governos democráticos no sentido de dar respostas, ainda que parciais, às demandas dos que sofreram arbitrariedades durante o regime civil-militar. Por fim, Lucia Elena Bastos apresenta um painel bastante amplo das Leis de Anistia na América Latina, examinando-as à luz do direito internacional.

Os capítulos da seção final do livro são voltados para questões relativas à construção democrática no Brasil. Heloísa Greco, em "Anistia anamnese VS. Anistia amnésia: dimensão trágica da luta pela anistia", além de registrar a pouca importância dada pela historiografia ao estudo do caráter instituinte da luta pela anistia, analisa os fundamentos das estratégias de esquecimento que têm sido acionadas por diferentes governos, contando para tal com apoio da mídia e de amplos setores da sociedade brasileira. Edson Teles fecha o livro passando em revista os principais temas e questões abordados nos dois volumes: os limites do consenso da transição pactuada; a política de silêncio em torno dos desaparecidos; os problemas em torno do acesso aos arquivos do regime.

Concluída a leitura dos dois volumes, há muito a se discutir a respeito do duro diagnóstico de boa parte dos autores acerca da maneira pela qual a democracia brasileira tem lidado com os inúmeros problemas do passado. $\mathrm{O}$ que importa aqui, no entanto, é registrar, uma vez mais, a relevância da obra para a historiografia e para a cidadania brasileiras. 